\title{
RESEARCH
}

Open Access

\section{Pedagogies for the open knowledge society}

Paola Ricaurte

\author{
Correspondence: pricaurt@itesm.mx \\ Humanities and Social Sciences, \\ Tecnologico de Monterrey, Mexico \\ City Campus, Calle del Puente 222, \\ Col. Ejidos de HuipulcoCP 14380 \\ Tlalpan, Mexico City
}

\begin{abstract}
Learning challenges within the knowledge society cannot be limited to the technological dimension. Learning and education are embedded in economic, political and cultural contexts. Pedagogies reflect this social condition. Consequently we need to situate the pedagogical practices on a wider debate regarding their place in the global system of knowledge production. Some questions are relevant in assessing these practices: What is the sense of learning in the knowledge society? How this technological paradigm modifies our conception of learning and education? How pedagogies are related to technology and the global system of knowledge production? What principles are associated with these proposals? Through a case study of two learning environments, Wikipedia and Google, we compare the two models and the values, principles and competences associated to each of them.
\end{abstract}

Keywords: Network society, Information society, Open learning environments, Wikipedia, Google, Emerging pedagogies

To remain human and liveable, knowledge societies will have to be societies of shared knowledge.

(United Nations, 2005, p. 5)

\section{Introduction}

The current state of the development of capital, which some authors have called information society (Masuda, 1981), knowledge society (Drucker, 1993), network society (Castells, 1996), knowledge economy (Powell \& Snellman 2004) or, from a critical perspective, cognitive capitalism (Moulier-Boutang, 2012) is characterized by the role knowledge gains as the main value in the accumulation of capital (Vercellone, 2007). While is true that the ways in which we can define this age and its features possess substantial distinctions, authors agree that information and communication technologies constitute an essential dimension in the creation, dissemination and use of the knowledge and, therefore, in society's structural transformation processes (Castells \& Cardoso, 2005).

The term knowledge society has been the preferred option by international organizations because it highlights that it is knowledge -the capacity to create new meanings, and not information or technology-, which allows for the improvement of human condition (United Nations, 2005). On the contrary, Castells (1996), Castells and Cardoso (2005) 
maintains that the interconnected characteristic of society, derived from the possibilities offered by communication technologies, and not just information or knowledge, it's what defines its fast, global and complex nature in every age in history. For Castells the technologyinformation paradigm is what defines the current type of social organization. This new form of organization reconfigures the mechanisms of power, notions of time and space, institutions, sociality, work, and forms of cultural production and cultural action. To authors like Vercellone (2007) it is important to differentiate that knowledge society is the evolution of a post-Fordism capitalism, which is founded on the exploitation of cognitive work, creating a new space for conflict between work and knowledge. Cognitive capitalism's thesis emerges as a critique of knowledge based economy.

As a result of this new configuration within global social organization new inequalities, new forms of exclusion and new uses of power through knowledge control emerge from those nations who insert themselves in knowledge society. An alternative paradigm is the one proposing to speak about knowledge societies based on a collaborative economy not governed by market laws (Kostakis \& Bauwens, 2014) whose characteristics are peer production (Bauwens, 2006; Benkler, 2006; Benkler, Shaw, \& Hill, 2015) and a notion of knowledge not as merchandise (Powell \& Snellman, 2004) but as a common good which can be defended and shared (Bollier, 2007; Hess \& Ostrom, 2007; Ostrom, 1990).

This dynamic techno-social scenario entails deep transformations: on a macro level in the processes of knowledge production and capital accumulation; on a medium level in the transformation of education and educative institutions; and on a micro level in the learning processes, which must be understood as a complex interdependent relationship. Through contrasting two paradigmatic technology platforms of knowledge society, Google and Wikipedia, we propose to show how they respond to two different models of value accumulation that materialize in pedagogical practices. We start from the hypothesis that pedagogic tendencies contribute to shape a given model of knowledge society that reflects the close interconnections between micro, meso and macro social levels.

\section{Education and technology in knowledge economy}

According to David and Foray (2003, p. 22 and the following) knowledge economy is characterized by the massive and extremely fast acceleration of knowledge production; intangible capital growth on a macroeconomic level, through the investment in human capital, education and the dissemination of knowledge; innovation; a revolution in knowledge instruments: and information and communication technologies. The link between socio-technical context and education and economy is visible on different levels: a) the educative industry, which hand in hand with the technology industry allows for mass knowledge production; b) development of abilities through training human capital (workers and creators in knowledge economy), establishing and reproducing the rules for knowledge production and dissemination, and defining educative models, curricula and pedagogies that allow to outline teaching and learning (Gurung, 2013), as well as the emphasis on adopting technology and developing digital competences to incorporate and advance in knowledge society; c) investment in innovation and the education's role in the development of creative abilities, the positive valuation of scientific areas and their inclusion in the curricula as priority; the 
systematization of innovation processes, and scientific and technological progress; d) investing in the development of technology infrastructures that facilitate the creation of networks that allow the flux of information, as well as knowledge creation and transference. Based on these elements it would be possible to establish education as an essential mechanism, part of the generation, transference and appropriation of knowledge and, therefore, as one of the pillars of global economy.

The close relationship between technology and education has created a prolific field of study which, through diverse approaches, looks to characterize the nature, impact and the meaning of the transformations in the learning process. There are numerous studies that approach the problem of infrastructure technologies intervention in the cognitive or pedagogic processes. Others focus on appropriation models and the use of devices or platforms (Internet, mobiles, social networks, applications) in the educative context and its impact on learning, without highlighting the pedagogic processes. It is less frequent to find the argument focusing on the analysis of the relationship between technology systems and knowledge production systems, or ones that propose models to analyze learning in digital contexts in terms of economy, politics and emotion (McCann, 2014). In respect to the questions that we ask ourselves, Postman (1993) considers that what is important about technology is not its efficiency as a learning tool, but the way in which modifies our notion of learning and, on other level, and the way that the ecology of media (McLuhan, 1994) in conjunction is modifying the idea of the educative institution.

In the case of public policy, we see in the governmental and institutional discourse the absence of consideration about linking educative models with technological development and the global ecosystem of knowledge production. In general terms, educative innovation initiatives in educative institutions at any level limit themselves to reproducing the narratives and models designed by the agendas of technology corporations, and in a few occasions they consider original pedagogic proposals that contribute to a critical reflection about learning processes in relation to technology. Exceptionally it is possible to find institutional discourses that on a macro level (as is the case of Uruguay) and micro level (as in some disruptive schools), are interested in framing pedagogic practices and learning in a context that allows to evaluate its influence in the local and global knowledge production systems. Because of this, it is important to highlight that proposals which emphasize the technological dimensions of learning in a network and not its pedagogic dimensions contribute to (or are motivated by) the initiatives of technology corporations that have in the educative institutions and in governments their main clients.

\section{Pedagogic tendencies for the digital Age}

The group of socio-technical context transformations and its implications in the field of pedagogy has generated abundant papers in the scholarly literature. There are publications that provide an outlook of the pedagogic tendencies emerging in the digital age (Bates, 2015; Beetham, McGill, \& Littlejohn, 2009; Cartelli, 2006; de Oliveira et al., 2015; Limbu, 2014; Yáñez, Okada, \& Palau, 2015). Next we'll talk about these tendencies. It is not an exhaustive survey, and its sole purpose is to illustrate certain trends in today's pedagogic debate. 
A group of pedagogic approaches that emerged in recent years locates its origin in the social construction of learning (Dewey, 1897; Vigotsky, 2000). They expand classical perspectives on the zone of proximal development (Vigotsky, 2000) in the digital context and include approaches from network society theory (Castells, 1996) and cognition (Downes, 2012, Siemens, 2005). It is also possible to find ramifications in the understanding of learning's social character as a process located (Wenger, 2009) and materialized in the concept of communities of practice (Lave, 1991; Lave \& Wenger, 1991; Wenger, 1999) and applied to learning in digital contexts.

Authors such as Cabero (2006), Suárez (2010) and Suárez and Gros (2013) have explored e-learning's advantages and reach, reflecting on internet as an educative environment and the pedagogic use of "social software" (McLoughlin \& Lee, 2010). In this tendency, Internet is considered a learning environment that should be approached pedagogically, as proposed by networked pedagogy (Suárez, 2014). Associated to the need to emphasize connected learning we find the research on personal learning environments (PLE) and personal learning networks (PLN), both of which take advantage of technological tools to create environments and networks that potentiate learning (Adell \& Castañeda, 2010, 2013; Castañeda \& Adell, 2013). Another group approaches this learning methods through specific digital platforms, as MOOC (Massive Online Open Courses), social networks and other applications (Alemán, Sancho \& Gómez, 2015; Gallardo, Marqués, \& Bullen, 2015; Kigozi, Vesisenaho, Hansson, Danielson, \& Tusubira, 2012; Roig Vila, Mengual-Andrés, \& Suárez Guerrero, 2014; Santally, 2005).

Another approach comes from a series of meta-theories studying learning processes in a network. This is the case of distributed cognition (Hutchins, 2006; Salomon, 1993) which maintains that cognitive processes may be distributed through the members of a social group. These approaches have used network theory (Barker \& Kemp, 1990) and also Latour's (2005) actor-network theory as a pedagogic proposal (Fenwick \& Edwards, 2010; Fox, 2002) or as an analytical resource to understand learning processes.

Digital convergence and mobility offered by technology have made way for proposals that exploit these features. Aparici and Silva (2012) in Pedagogy of Interactivity explain how interactivity reflects on the value of participation, dialogue and co-authorship, features that are also common to the principles of participative web. McGonigal (2011) proposed to include videogames as pedagogic tools, which allow solving real problems.

In general, on another block, we can identify some trends that reflect on learning in digital environments and that focus in the development of participatory cultures (Jenkins, 2009), collective peer production (Bauwens, 2006; Benkler, 2006; Benkler et al., 2015; Rheingold, 2014), the necessary competences to take advantage of learning possibilities self-suggested by the digital environment (Rheingold, 2014), and common goods (Lafuente, Alonso, \& Rodríguez, 2013; Ostrom, 1990). Other authors go back to the foundations of cooperation theories to develop a group of patterns on the learning process in diverse contexts, including digital, as is the case of peer pedagogy (peeragogy) (Rheingold, 2014, Ricaurte, 2013). In the latter, learning is associated to cooperation principles, free software, free culture, and peer production (Corneli, Danoff, Peirce, Ricaurte, \& MacDonald, 2015). A different aspect offered is one in which proposals conceive learning and knowledge production as a citizen's process, self-regulated and inscribed in a "makers" culture (Lafuente, 2013; Lafuente et al., 2013; Lafuente \& García, 2015), which in a way recovers the spirit of critical pedagogy (Freire, 1970), 
experiential learning (Kolb, 2014), and even located learning (Lave \& Wenger, 1991). This vision emphasizes the need for a form of learning that allows the apprentice to perceive its surrounding needs, to act in consequence, collectively and with self-regulation, hand in hand with the possibilities of digital production through free technologies. With respect to practices and resources, Coughlan and Perryman (2013) argue that Open Educational Practices (OEP) and Open Educational Resources (OER) promote innovative pedagogic models that encourage the creation of communities and collaboration (UNESCO, 2012).

The pedagogical trends reviewed show a vision of the student as an essential agent of the process. Also it is possible to distinguish in them certain common principles as participative culture, network learning, cooperation and openness. However, not all proposals necessarily commit themselves to free culture, through open licenses or the preference of free technology - proposals which could be associated with a vision of an open knowledge society-, over the private. With exception of the pedagogies associated to a concept of knowledge as commons (Bollier, 2007), in general, among the pedagogic approaches, the relationship between their pedagogic goal, the knowledge production system and its implication in the social order is not made explicit.

\section{Wikipedia and Google: Two paradigms in knowledge economy}

The emergence of new trends or the reformulation of classical theories makes the universe of possibilities for approaching learning in digital contexts a complex task. However, there are profound implications to making pedagogic decisions outside of knowledge production's global context. We feel it is pertinent to promote an educative culture that doesn't contribute to the concentration of power and capital through knowledge. Because of this, we propose through a case study of two learning environments, Wikipedia and Google, to carry out an analysis that allows us to compare these two models of knowledge society materialization. We chose these two learning environments because they constitute the most representative cases of two opposed paradigms in the Internet universe.

\section{Wikipedia}

With almost 375 million visitors each month, Wikipedia is the seventh most visited site in the world (Wikipedia, 2016). It is the largest encyclopedia in the history of humanity and constitutes the largest resource of open knowledge production created through crowdsourcing. Their motto is "Imagine a world in which every single person on the planet is given free access to the sum of all human knowledge. This is what we're doing".

Wikimedia Foundation, to which Wikipedia is subordinate, is a non-profit organization. It supports itself through user donations. Since it isn't a company, one can only estimate its value, which would be along the lines of tens of billions of dollars (Eveleth, 2013). It isn't an organization in the traditional sense; it is a community with several projects: Wikimedia Foundation, Wikipedia Education Program, GLAM (Galleries, Libraries, Archives and Museums), Wiki Initiative, Wikimedia Commons (a repository of images and other resources), and the events of the Wikimedia Foundation (Wikimania, Wikicontests, etc.). Each of these areas has its own projects and a series of associated organizations and initiatives. Their editors are volunteers. The training for the 
editors (students, teachers or general users) is imparted through manuals and tutorials with Creative Commons licensing, free for downloading. The communities are connected through mailing lists, through the discussion page of the articles, through wiki itself, and others places on the web (social networks, in-person meetings, edit-a-thons, etc.). There's also a volunteer mentor program that supports students or teachers who wish to use Wikipedia as an educative tool.

\section{Google}

Google Inc. is the most important Internet company. Their mission "is to organize the world's information and make it universally accessible and useful". It is a multinational technology company specializing in services and products related to the Internet. Their products are adds, searches, cloud computing and software. Since 2015 they are part of Alphabet, a multinational conglomerate that groups Google products and others such as Nest Labs, Jigsaw, Verily, etc. In 2015 the conglomerates earnings reached 75 billion dollars (Wikipedia, 2016). A share on the Stock Exchange costs 742 dollars.

Google's educative program, Google for Education, offers products, training and resources. The products are devices (Chromebook), productivity tools (Drive, Gmail, Calendar, etc.), Classroom (course management platform). Their training is an in depth program in Google tools for teachers at all levels. The courses are guided and designed for the classroom's needs. The content is free, but program certification is not. Certification involves taking multiple choice tests. In case of failing the level's certification test it is necessary to pay again the test fee to receive a new opportunity to take the test again. It consists of four certifications levels: Educator level 1, Educator level 2, Certified Instructor and Certified Innovator. Among the resources, we can find communities of educators that use Google, programs for teachers and students, and instruction on informatics.

These two learning environments, that apparently could be considered open, in reality present profound differences in respect to the place they occupy in the knowledge production system, their pedagogic offer, the values associated to their initiatives and the types of competences they develop. In Table 1 we present the most important differences.

\section{Discussion}

Through Google's and Wikipedia's platforms it is possible to see the contrast between two models for approaching knowledge production, dissemination and consumption. Both platforms may be considered open learning environments and may be included, for example, as part of the personal learning environments (PLE) of teachers and students (Adell \& Castañeda, 2010, 2013; Castañeda \& Adell, 2013). However, the choice of one technology over the other implies taking a stand in respect to a specific paradigm in knowledge economy (Powell \& Snellman, 2004).

The model of peer knowledge production (Bauwens, 2006; Benkler, 2006; Benkler et al., 2015) which constitutes Wikipedia's essence may be conceived as part of an epistemology and methodology of peer learning (Rheingold, 2014) and peer production (Bauwens, 2006). Using Wikipedia as an open learning environment meets the objective of supporting networks and the necessary global participation structures for the emergence of open knowledge societies. Wikipedia promotes a notion of knowledge as commons. Therefore, ascribes to a culture of free licenses that allow for the use, reuse, and remix of contents that have been generated by everyone and, in consequence, should not be hoarded. Its use as an open learning environment shows possibilities in all three 
Table 1 Wikipedia and Google: Two Paradigms in Knowledge Economy

\begin{tabular}{|c|c|c|}
\hline Platform & Wikipedia & Google \\
\hline \multirow{2}{*}{$\begin{array}{l}\text { Type of } \\
\text { organization }\end{array}$} & Foundation & Corporation \\
\hline & Non Profit & For profit \\
\hline $\begin{array}{l}\text { Education } \\
\text { program }\end{array}$ & $\begin{array}{l}\text {-Wikimedia Foundation Education Program } \\
\text {-Education Collaborative } \\
\text { A group of education leaders around the world } \\
\text { who volunteer to mentor education initiatives }\end{array}$ & $\begin{array}{l}\text {-Google for Education } \\
\text { Official Google program for educators and } \\
\text { educative institutions }\end{array}$ \\
\hline Certification & No formal certification process & $\begin{array}{l}\text { Official certification through payment, with } \\
\text { predefined levels and processes by the } \\
\text { company }\end{array}$ \\
\hline Community & $\begin{array}{l}\text { Communities in different spaces (Wikimania, } \\
\text { Collaborative Education, Education Program) } \\
\text { and other places on the network }\end{array}$ & $\begin{array}{l}\text { Learning communities within their own } \\
\text { environment (like Google }+ \text { ) }\end{array}$ \\
\hline Privacy & Commitment with personal data privacy & $\begin{array}{l}\text { No real commitment with personal data } \\
\text { privacy. }\end{array}$ \\
\hline Principles & $\begin{array}{l}\text {-Open Knowledge } \\
\text {-Free software } \\
\text {-Free culture (Creative Commons Licensing or } \\
\text { public domain) } \\
\text {-Remix Culture } \\
\text {-Wiki } \\
\text {-Collective Knowledge Production }\end{array}$ & $\begin{array}{l}\text {-Service "free of charge", but associated to } \\
\text { personal data industry. } \\
\text {-Free software, but their algorithm's code, } \\
\text { Page Rank, is not open. } \\
\text {-lt's a business associated to the obtaining of } \\
\text { new clients for their platforms. } \\
\text {-Hierarchical organization and control of } \\
\text { knowledge. }\end{array}$ \\
\hline $\begin{array}{l}\text { Pedagogic } \\
\text { values }\end{array}$ & $\begin{array}{l}\text { Associated with the universal access to open } \\
\text { knowledge and the collective production in the } \\
\text { different projects of the Wikimedia Foundation } \\
\text { (Wikimedia Commons, Wikipedia, Wikibooks, } \\
\text { Wikiversity, etc.) }\end{array}$ & $\begin{array}{l}\text { Associated to the use and appropriation of } \\
\text { different platforms form the Google } \\
\text { ecosystem (Gmail, Youtube, Calendar, Drive, } \\
\text { Hangouts, Google+, Blogger). }\end{array}$ \\
\hline Competences & $\begin{array}{l}\text {-Collaborative production } \\
\text {-Sharing } \\
\text {-Community building } \\
\text {-Basic (reading-writing), intercultural and digital } \\
\text { competences. }\end{array}$ & $\begin{array}{l}\text {-Collaborative production } \\
\text {-Sharing } \\
\text {-Building communities } \\
\text {-Digital competences associated to their } \\
\text { platforms }\end{array}$ \\
\hline Prestige & $\begin{array}{l}\text {-The more you edit the bigger the recognition } \\
\text { one receives from the community } \\
\text {-Program of volunteer mentors (education } \\
\text { leaders) to promote the use of Wikipedia } \\
\text { among students and educators. }\end{array}$ & $\begin{array}{l}\text {-The one who is certified is recognized, the } \\
\text { one who isn't is institutionally and/or socially } \\
\text { chastised. }\end{array}$ \\
\hline
\end{tabular}

levels previously mentioned. On a micro level: as a pedagogic option for the development of basic, digital and research competences. On an institutional or medium level: since adopting it involves a change in the institutional culture, especially with respect to the evaluation system, the perception of the encyclopedia's validity, the culture of respect towards copyright and the dissemination of knowledge.

For their part, Google has a policy of centralization and knowledge control; while it's true that the company has access, for example, to the largest digital library on the planet, it is them together with the content production industries who decide the limits for their users. Another aspect is that their algorithm for hierarchical organization of content is not open. While its mechanism is known, its code is not open and, therefore, we don't have the possibility to partake in establishing said algorithm. Another relevant aspect is the destiny of personal data and their captive users through their cloud services, like e-mail or Drive, their suite for collective production. Google's influence also appears on the three levels. On a micro level we've seen how users give up their right to their personal data privacy in exchange for their services. On an institutional level, it signs commercial agreements with educative institutions to offer their services 
and training programs. And on a macro level, it carries out lobbying among politicians and governments for their products and services to be included in digital agendas, or to receive support for those public policies which benefit the company.

\section{Conclusion}

Through this text we've maintained that the debate around knowledge society and the role of education in it is in permanent tension between two forces: on the one hand, the prevalence of a form of accumulating value, based on intangible and infinite common goods, that is, knowledge as merchandise; and on the other, alternative forms of value production associated to the commons and commons governance (Hess \& Ostrom, 2007; Ostrom, 1990). This tension is reflected in the different levels of knowledge society associated with education. On the macro level through the educative and technology industries and public policies; on the medium level, through institutional transformations which define curricula, competences and educative models; and on the micro level, in the pedagogic practices that materialize in the specified decisions about the learning process and its relationship with technology.

The values of openness, cooperation, learning in a network and collective production of knowledge are present in many pedagogic trends that have emerged in recent years. By comparing the cases of Wikipedia and Google, we can find that in spite of some shared features, like digital training for teachers and students, the creation of learning communities or the possibility for developing similar competences, it's also true that they have important differences and that mainly these are because Google initiatives in education are related to the commercialization of their products and to increase their user base. Therefore, the structure and organization of their educative programs are guided by this condition.

We need studies that evaluate the theoretical and practical proposals, the pedagogic discourses and the educative models in the scope of a global system for knowledge production and technology development, characterized by the centralization and restriction of access to contents and the development of personal data industries. The proposals on learning in digital environments cannot be limited to the use of platforms, resources, devices, mobile applications without situating all of these in the material, relational and sociocultural context they come from.

\footnotetext{
Authors' information

Paola Ricaurte holds a Language Science PhD from the National School of Anthropology and History (Mexico). Currently, she is a Professor and Researcher at the Graduate School of Education, Social Sciences and Humanities at Tecnológico de Monterrey, Mexico City Campus. She is the Director of Openlabs, a citizen lab for social and education innovation: http://www.openlabs.mx/.
}

Competing interests

The author declares that has no competing interests.

Received: 13 December 2015 Accepted: 19 May 2016

Published online: 31 August 2016

References

Adell, J., \& Castañeda, L. (2010). Personal learning environments: a new way to understand learning. In M. Roig \& M. Fiorucci (Eds.), Clues for research on innovation and education quality. Alcoy: Marfil-Roma TRE.

Adell, J., \& Castañeda, L. (2013). The pedagogical ecosystem of personal learning environments. In Castañeda, L. \& Adell, J. (Ed.). Personal learning environments. clues for the educational network ecosystem. Alcoy: Marfil-Roma TRE.

Alemán, L. Y., Sancho, T., \& Gómez, M. G. (2015). Indicators of pedagogical quality for the design of a Massive Open Online Course for teacher training. RUSC. Universities and Knowledge Society Journal, 12(1), 104-119. http://dx.doi.org/10.7238/rusc.v12i1.2260. Accessed 23 Nov 2015 
Aparici, R., \& Silva, M. (2012). Pedagogy of interactivity. Comunicar, 19, 38. http://dx.doi.org/10.3916/C38-2012-02-05. Accessed 23 Nov 2015

Barker, T. T., \& Kemp, F. O. (1990). Network theory: A postmodern pedagogy for the writing classroom. In C. Handa (Ed.) Computers and community: Teaching composition in the twenty-first century (pp. 1-27). Portsmouth, NH: Boynton/ Cook Publishing.

Bates, A. W. (2015). Teaching in a digital age: Guidelines for designing teaching and learning. British Columbia: BC Open Textbooks. http://bit.ly/1T53L46. Accessed 20 Nov 2015

Bauwens, M. (2006). The political economy of peer production. Post-autistic Economics Review, 37, 33-44. http://bit.ly/ 1S368PL. Accessed 20 Nov 2015

Beetham, H., McGill, L., \& Littlejohn, A. (2009). Thriving in the 21st century: Learning Literacies for the Digital Age. The Caledonian Academy, Glasgow Caledonian University. UK: JISC.

Benkler, Y. (2006). The wealth of networks: How social production transforms markets and freedom. New Heaven: Yale University Press.

Benkler, Y., Shaw, A. \& Hill, B. M. (2015). Peer Production: A Form of Collective Intelligence. In T. W. Malone \& M. S. Bernstein (Eds.), Handbook of Collective Intelligence. Cambridge, MA: MIT Press.

Bollier, D. (2007). The growth of the commons paradigm. Understanding knowledge as a commons. Cambridge, MA: MIT Press.

Cabero, J. (2006). Pedagogical foundations of e-learning. RUSC, Universities and Knowledge Society Journal, 3, 1. http://bit. ly/1cdgXtd. Accessed 19 Nov 2015

Cartelli, A. (2006). Teaching in the Knowledge Society: New Skills and Instruments for Teachers. Hershey, PA: Information Science Publishing.

Castañeda, L., \& Adell, J. (Eds.). (2013). Personal learning environments. Clues for the educational network ecosystem. Alcoy: Marfil.

Castells, M. (1996). The information age: economy, society and culture. The rise of the network society (Vol. 1). Oxford: Blackwell.

Castells, M., \& Cardoso, G. (Eds.). (2005). The Network Society: From Knowledge to Policy. Washington, DC: Johns Hopkins Center for Transatlantic Relations.

Corneli, J., Danoff, C., Peirce, C., Ricaurte, P. Y., \& MacDonald, L. (2015). Patterns of Peeragogy. Pittsburg, PA: International Conference on Pattern Languages of Programs.

Coughlan, T., \& Perryman, L. A. (2013). Beyond the ivory tower: a model for nurturing informal learning and development communities through open educational practices. RUSC. Universities and Knowledge Society Journal., 10(1), 312-326. http://dx.doi.org/10.7238/rusc.v10i1.1586. Accessed 23 Nov 2015

David, P. A., \& Foray, D. (2003). Economic fundamentals of the knowledge society. Policy Futures in Education, 1(1), 20-49.

de Oliveira, J. M., Henriksen, D., Castañeda, L., Marimon, M., Barberà, E., Monereo, C., Coll, C., Mahiri, J., \& Mishra, P.

(2015). The educational landscape of the digital age: communication practices pushing (us) forward. RUSC. Universities and Knowledge Society Journal, 12(2), 14-29. http://dx.doi.org/10.7238/rusc.v12i2.2440. Accessed 23 Nov 2015

Dewey, J. (1897). My pedagogic creed. School Journal, 54, 77-80. http://bit.ly/1J4KmcX. Accessed 18 Oct 2015

Downes, S. (2012). Connectivism and Connective Knowledge. http://www.downes.ca/files/books/Connective_Knowledge19May2012.pdf. Accessed 15 Nov 2015

Drucker, P. F. (1993). The rise of the knowledge society. The Wilson Quarterly, 17(2), 52-71.

Eveleth, R. (2013). How Much is Wikipedia Worth? Smithsonian. http://bit.ly/1ZnS1do. Accessed 15 Nov 2015

Fenwick, T., \& Edwards, R. (2010). Actor-network theory in education. New York: Routledge.

Fox, S. (2002). Studying networked learning: some implications from socially situated learning theory and actor network theory. In C. Jones \& C. Steeples (Eds.), Networked learning: perspectives and issues. London: Springer.

Freire, P. (1970). Pedagogy of the oppressed. New York: Continuum

Gallardo, E., Marqués, L., \& Bullen, M. (2015). Students in higher education: Social and academic uses of digital technology. RUSC. Universities and Knowledge Society Journal, 12(1), 25-37. doi:10.7238/rusc.v12i1.2078

Gurung, B. (2013). Emerging pedagogies in changing contexts: pedagogies in networked knowledge society. Journal of Global Literacies, Technologies, and Emerging Pedagogies, 1(2), 105-124.

Hess, C., \& Ostrom, E. (2007). Understanding Knowledge as a Commons. Cambridge, MA: MIT Press.

Hutchins, E. (2006). The distributed cognition perspective on human interaction. Roots of human sociality. Culture, cognition and interaction, 1, 375 .

Jenkins, H. (2009). Confronting the Challenges of Participatory Culture. Cambridge, MA: MIT Press.

Kigozi, E., Vesisenaho, M., Hansson, H., Danielson, M., \& Tusubira, F. F. (2012). Modelling a peer assignment review process for collaborative E-learning. Journal of Interactive Online Learning, 11, 2.

Kolb, A. (2014). Experiential Learning. 2nd ed. Upper Saddle River, NJ: Pearson.

Kostakis, V., \& Bauwens, M. (2014). Network society and future scenarios for a collaborative economy. London, New York: Palgrave Macmillan.

Lafuente, A. (2013). Citizen science: itineraries of the amateur, activist and hacker. national institute of educational technologies and teacher training. Educalab. Blog. [online] http://bit.ly/1UJJmQ3. Accessed 15 Oct 2015

Lafuente, A., Alonso, A., \& Rodríguez, J. (2013). We are all wise! Citizen science and expanded knowledge. Madrid: Cátedra.

Lafuente, A. Y., \& García, M. (2015). Citizen labs: expanded knowledge, colateral science and experimental politics. http://bit. ly/1MkpDaD. Accessed 19 Nov 2015

Latour, B. (2005). Reassembling the Social. An Introduction to Actor-Network-Theory. Oxford: Oxford University Press.

Lave, J. (1991). Situating learning in communities of practice. Perspectives on socially shared cognition, 2, 63-82.

Lave, J., \& Wenger, E. (1991). Situated learning: Legitimate peripheral participation. Cambridge: Cambridge University Press.

Limbu, M. (2014). Emerging Pedagogies in the Networked Knowledge Communities: Interweaving and Intersecting Global Communities in the 21st Century Global Village. In M. Limbu \& B. Gurung (Eds.), Emerging Pedagogies in the Networked Knowledge Society: Practices Integrating Social Media and Globalization. Hershey, PA: Information Science Reference. doi:10.4018/978-1-4666-4757-2.ch003 
Masuda, Y. (1981). The Information Society as Post-industrial Society. Bethesda, MD: World Future Society.

McCann, A. (2014). Emotional and Political Possibilities of Pedagogy in Virtual Worlds. Blogpost, http://bit.ly/1gUkbFP. Accessed 7 Sep 2015

McGonigal, J. (2011). Reality is broken: Why games make us better and how they can change the world. New York: The Penguin Press.

McLoughlin, C., \& Lee, M. (2010). Personalised and self regulated learning in the Web 2.0 era: international exemplars of innovative pedagogy using social software. Australasian Journal of Educational Technology, 26(1), 28-43.

McLuhan, M. (1994). Understanding media: The extensions of man. Cambridge, MA: MIT Press.

Moulier-Boutang, Y. (2012). Cognitive capitalism. Cambridge: Polity Press.

Ostrom, E. (1990). Governing the commons: The evolution of institutions for collective action. Cambridge: Cambridge University Press.

Postman, N. (1993). Technopoly: The surrender of culture to technology. New York: Vintage Books

Powell, W. W., \& Snellman, K. (2004). The knowledge economy. Annual Review of Sociology, 30, 199-220.

Rheingold, H. (Ed.). (2014). The Peeragogy Handbook. A guide for Peer-Learning and Peer Production. V. 2.. Arlington, MA Peirce Press.

Ricaurte, P. (2013). Peeragogy. In D. Aranda, A. Creus, \& J. Sánchez Navarro (Eds.). Education, digital media and participatory culture. Barcelona: UOC Press.

Roig Vila, R., Mengual-Andrés, S., \& Suárez Guerrero, C. (2014). Assessing the pedagogical quality of MOOCs. Faculty, 18, 1. http://bit.ly/1gUkbFP. Accessed 18 Oct 2015

Salomon, G. (1993). Distributed cognitions: Psychological and educational considerations. Cambridge: Cambridge University Press.

Santally, M. (2005). From face-to-face classrooms to innovative computer mediated pedagogies: observations from the field. Journal of Interactive Online Learning, 3, 4.

Siemens, G. (2005). Connectivism: a learning theory for the digital Age. International Journal of Instructional Technology and Distance Learning, 2, 1. http://www.itdl.org/Journal/Jan_05/article01.htm. Accessed 15 Nov 2015

Suárez, C. (2014). Network pedagogy. Pedagogy notebooks (p. 449). http://bit.ly/1vyYibA. Accessed 20 Oct 2015

Suárez, C. (2010). Cooperation as the social condition for learning. Barcelona: UOC Press.

Suárez, C., \& Gros, B. (2013). Networked learning: from interaction to cooperation. Barcelona: UOC Press.

United Nations. (2005). Towards Knowledge Societies. Paris: UNESCO Publishing.

UNESCO. (2012). Open Educational Resources. http://bit.ly/1aPI58f. Accessed 17 Nov 2015

Vercellone, C. (2007). From formal subsumption to general intellect: elements for a marxist reading of the thesis of cognitive capitalism. Historical Materialism, 15(1), 13-36.

Vygotsky, L. (2000). The development of higher psychological processes. Barcelona: Crítica.

Wenger, E. (2009). A social theory of learning. In K. Illeris (Ed.), Contemporary theories of learning: learning theorists-in their own words. New York: Routledge.

Wenger, E. (1999). Communities of practice: Learning, meaning, and identity. Cambridge: Cambridge University Press. Wikipedia. (2016). About. https://en.wikipedia.org/wiki/Wikipedia:About. Accesed 19 July 2016

Yáñez, C., Okada, A., \& Palau, R. (2015). New learning scenarios for the 21 st century related to education, culture and technology. RUSC. Universities and Knowledge Society Journal, 12(2), 87-102. http://dx.doi.org/10.7238/rusc.v12i2.2454

\section{Submit your manuscript to a SpringerOpen ${ }^{\circ}$ journal and benefit from:}

- Convenient online submission

- Rigorous peer review

- Immediate publication on acceptance

- Open access: articles freely available online

- High visibility within the field

Retaining the copyright to your article 